\title{
Unødvendige nyord om avhengighet
}

\author{
Det er ikke behov for en egen betegnelse for skadelig bruk av opioider \\ forårsaket av legebehandling.
}

I et innlegg i språkspalten i Tidsskriftet nr. 22/2008 tar Olav Magnus Fredheim og medarbeidere til orde for å bytte ut begrepene «misbruk» og «avhengighet» med begrepene «problematisk opioidbruk», «addiksjon» og «iatrogent påført feilbruk» fordi disse er mer presise for pasienter som behandles med opioider (1). De ønsker en egen terminologi for vansker som oppstår etter forskrivning av opioide midler. Dette til tross for at forskningen viser grunnleggende nevrobiologiske fellestrekk ved ulike avhengighetstilstander. Deres beskrivelse av dagens begreper er dessuten for enkel, og konklusjonene blir derfor feil. Det er riktig at begrepet «misbruk» har et normativt preg. Misbruk innebærer at et middel brukes på en annen måte enn legen har bestemt eller på en måte som ikke er sosialt godtatt. Det er også riktig at begrepet «avhengighet» har flere betydninger. Noen av disse betydningene har lite med medikamenter og rusmidler å gjøre. Brukt i forhold til disse, er kjernen i begrepet at personen har en utilstrekkelig kontroll over bruken. Denne kontrollsvikten har både fysiske (toleransestigning og abstinens) og psykiske (sterk trang til bruk) elementer. Ved jevnlig bruk vil de fysiske fenomenene opptre også hos personer som ikke oppfyller kriteriene for en avhengighetsdiagnose. Av den grunn ønsker Fredheim og medarbeidere å droppe hele begrepet og heller omtale kun de psykiske elementene under betegnelsen «addiksjon».

Begrepene «misbruk» og «avhengighet» er i dag klart definerte diagnoser både $\mathrm{i}$ det amerikanske diagnosesystemet DSM-IV og i WHOs ICD-10. «Avhengighet» er knyttet til at man oppfyller minimum tre kriterier i løpet av ett år: toleranse, abstinens, større inntak enn planlagt, ønske om å redusere uten at dette skjer, mye tid brukt til å få tak i eller bruke substansen, bruken går utover andre ting i livet og bruk til tross for kunnskap om negative konsekvenser. Mange av pasientene som Fredheim og medarbeider omtaler, vil derfor ikke bli definert som «avhengige», selv om de både har utviklet toleranse og kan få abstinensreaksjoner! Vi er derfor uenige $i$ at det vil bedre forståelsen å se bort fra de fysiske komponentene ved avhengighet og kalle det «addiksjon». Internasjonalt har dessuten betegnelsen «addiction» vært oppfattet som for upresis til å brukes som diagnose.
På den annen side inngår ikke de farmakologiske komponentene toleranse og abstinensreaksjoner i diagnosen «misbruk». Fredheim og medarbeideres pasienter vil altså unngå en misbruksdiagnose selv om de har både toleranseutvikling og abstinensreaksjoner. Internasjonalt har det vært en bevegelse bort fra begrepet «abuse». I USA brukes delvis «misuse» som peker på at midlet brukes feilaktig. WHO har ønsket seg en mer medisinsk betegnelse og har valgt «harmful use». På norsk vil dette være «skadelig bruk» og kan knyttes til påvisbare psykiske eller fysiske skader. Dette er en mer presis betegnelse enn «problematisk bruk».

Fredheim og medarbeidere ønsker seg også en egen betegnelse for skadelig bruk som stammer fra legebehandling - «iatrogent oppstått feilbruk». Det kan være viktig å skjønne hvordan en tilstand oppstår, men i moderne diagnostikk tilstreber man å være deskriptiv og ikke vektlegge tilsynelatende årsaker. Forfatterne har sikkert opplevd at pasienten har startet sitt misbruk hos en lege. De er derfor velkomne til å bruke dette som avdelingssjargong, men dette egner seg ikke som diagnose. Vi tror ikke vi trenger denne diagnosen i tillegg til skadelig bruk, selv om den antakelig dekker et fenomen som andre forfattere velger å kalle «pseudoterapeutisk langtidsbruk» (2).

Fredheim og medarbeidere kan altså ha noe rett, men det er lite hensiktsmessig å introdusere nye diagnoser. Vi kan ikke ha et eget sett med diagnoser som er skreddersydd til opioidbehandling av smertepasienter. Og særlig ikke når begrepene kan virke tildekkende $\mathrm{i}$ forhold til farene for avhengighetsutvikling også i denne gruppen.

\section{Jørgen G. Bramness}

Helge Waal

Senter for rus og avhengighetsforskning Universitetet i Oslo

\section{Jørg Mørland}

Folkehelseinstituttet

\section{Litteratur}

1. Fredheim OM, Borchgrevink PC, Breivik H. Nye begreper knyttet til opioidbehandling. Tidsskr Nor Legeforen 2008; 128: 2626.

2. Griffiths RR, Weerts EM. Benzodiazepine selfadministration in humans and laboratory animals - implications for problems of long-term use and abuse. Psychopharmacology 1997; 134: 1-37.

\author{
Olav Magnus S. Fredheim \\ og medarbeidere svarer:
}

Vi er glad for engasjementet til Jørgen G. Bramness og medarbeidere i forbindelse med vårt innlegg (1). Deres kommentarer viser til fulle at det er behov for de nye begrepene «iatrogent påført feilbruk», «problematisk opioidbruk» og «addiksjon» for å beskrive ulike varianter av «avvikende medisinrelatert oppførsel» (aberrant drugrelated behavior) hos pasienter som behandles med opioider for smerte (2). Bramness og medarbeidere viser at kolleger med ekspertise innen rusbehandling ikke ser hvordan pasienter med alvorlige kroniske smertetilstander som bruker opioide analgetika på en uheldig måte, skiller seg fra pasienter med rusproblem som sitt primære helseproblem (3). For å identifisere disse pasientene tidlig og sette i verk tiltak for å hindre progresjon til alvorligere avhengighetstilstander, kreves både oppmerksomhet rundt problemet og egnede begreper for å beskrive pasientens situasjon. Begrepene iatrogent påført feilbruk, problematisk opioidbruk og addiksjon er etablerte begreper internasjonalt i smertemedisinen (4), mens «avhengighet» og «misbruk» virker unødig stigmatiserende i denne pasientpopulasjonen.

I det internasjonale smertemedisinske fagmiljøet er det enighet om at diagnosene fra kodeverkene til WHO (ICD-10) og den amerikanske psykiatriforeningen (DSM-IV) er uegnet for smertepasienter som langtidsbehandles med opioider. Disse diagnosene er alle utviklet for svært mange år siden for å beskrive stoffmissbruk innenfor det psykiatriske fagfeltet uten tanke på at langvarig opioidbehandling for kronisk smerte på et senere tidspunkt skulle bli anerkjent behandling. «Avhengighetssyndrom«(ICD10) og «medikamentavhengighet» (DSMIV) skiller ikke klart mellom illegalt bruk av opioider i rusøyemed, opioidbehandling mot smerte som har kommet ut av kontroll og korrekt smertebehandling med opioider. Begge disse diagnoseverkene har abstinens ved bråseponering og toleranse som to av henholdsvis seks eller sju diagnosekriterier, hvorav tre må være til stede. Imidlertid er toleranse alltid til stede ved langtidsbehandling og abstinenssymptomer vil alltid oppstå ved brå seponering, mens feilbe- 
handling eller underbehandling (for lav dose eller for kortvirkende opioid) fremprovoserer atferd som likner den rusmisbrukere ofte har. Slik pseudoaddiksjon grunnet iatrogent påført feilbruk kjennetegnes av at smerteplagene forsterkes og pasienten gjør alt hun kan for å få en tilstrekkelig opioiddose (5). Dette er grunnlaget for at begrepene vi presenterte, skiller de psykologiske og de fysiologiske komponentene knyttet til avhengighet. Dette er i tråd med et konsensusdokument utarbeidet av American Pain Society, American Academy of Pain Medicine og American Society of Addiction Medicine der man for smertepasienter skiller toleranse og fysisk (biologisk) avhengighet fra de atferdsmessige komponentene av addiksjon (6).

Vårt innlegg handlet ikke om å innføre nye diagnoser, og slett ikke om å innføre nye begreper innenfor et annet fagområde enn vårt eget. Vi presenterte begreper som mer presist beskriver tilstander hos smertepasienter som ikke beskrives tilstrekkelig spesifikt dersom det utelukkende benyttes diagnoser som brukes i pasientpopulasjoner der rus og misbruk er det primære problemet.

Den gruppen smertepasienter som er mest utfordrende å behandle, er de pasientene som har utviklet addiksjon i tillegg til sin kroniske smertetilstand. Disse pasientene er avhengige av et tett og godt samarbeid mellom russpesialister og smertespesialister, men kan i realiteten fort falle mellom flere stoler dersom fagfolkene ikke snakker samme språk. Til tross for at pasienter i denne gruppen oppfyller de diagnostiske kriteriene for «misbruk» og «avhengighet» slik diagnosene brukes i rusomsorgen, kan man ikke gjennom disse diagnosene alene beskrive pasientens problem presist, siden det da ikke kommer frem at pasienten har en alvorlig smertetilstand og at igangsettelse av behandling med opioider var medisinsk indisert. For å fremme kommunikasjonen om disse pasientene behøver vi begrepene vi presen-

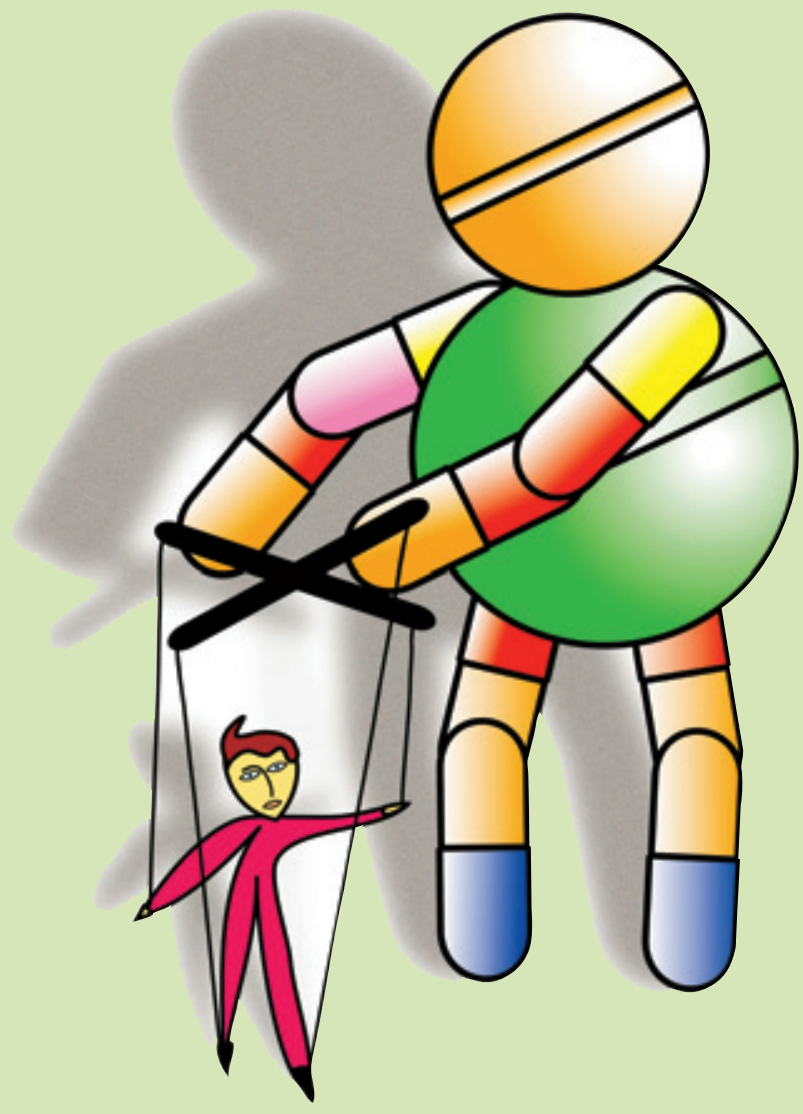

Illustrasjon Science Photo Library/GV-Press/NordicPhotos

terte - selv om de ikke er ment å bli nye formelle diagnoser.

\section{Olav Magnus S. Fredheim}

olavmagn@ntnu.no

Norges teknisk-naturvitenskapelige universitet og

Sykehuset Telemark

\section{Petter C. Borchgrevink}

Norges teknisk-naturvitenskapelige universitet og

St. Olavs hospital

\section{Harald Breivik}

Universitetet i Oslo

og

Rikshospitalet
Litteratur

1. Fredheim OM, Borchgrevink PC, Breivik H. Nye begreper knyttet til opioidbehandling. Tidsskr Nor Legeforen 2008: 128: 2626.

2. Dillie KS, Fleming MF, Mundt MP et al. Quality of life associated with daily opioid therapy in a primary care chronic pain sample. J Am Board Fam Med 2008; 21: 108-17.

3. Hojsted J, Sjogren P. Addiction to opioids in chronic pain patients: a literature review. Eur J Pain 2007; 11: 490-518.

4. Ballantyne JC, LaForge KS. Opioid dependence and addiction during opioid treatment of chronic pain. Pain 2007: 129: 235-55

5. Weissman DE, Haddox JD. Opioid pseudoaddiction - an iatrogenic syndrome. Pain 1989; 36: 363-6.

6. Savage SR, Joranson DE, Covington EC et al. Definitions related to the medical use of opioids: evolution towards universal agreement. J Pain Symptom Manage 2003; 26: 655-67. 